\title{
JIMMBA
}

\section{Pengaruh Attraction, Servicescape Wisata dalam Meningkatkan Revisit Intention Wisatawan dengan Visitor Satisfaction sebagai Variabel Intervening (Studi pada Obyek Wisata Bukit Pentulu Indah)}

\section{Mujiono1, Sigit Wibawanto ${ }^{2}$}

1,2Sekolah Tinggi Ilmu Ekonomi Putra Bangsa

Email: onomuji138@gmail.com¹, sigitpb3@gmail.com²

\section{ARTICLE INFO}

\section{Article History:}

Received: October26th 2020

Accepted: November 1st 2020

Published: December 1st 2020

\section{Keywords:}

Attraction, Servicescape, Visitor Satisfaction, Revisit Intention

\begin{abstract}
Penelitian ini bertujuan untuk menguji pengaruh Attraction dan Servicescape terhada Revisit Intention melalui Visitor Satisfaction sebagai variabel intervening. Metode pengambilan sampel yang digunakan adalah teknik Nonprobability sampling adalah teknik pengambilan sampel yang tidak diberi peluang/ kesempatan bagi setiap unsur atau anggota populasi untuk dipilih menjadi sampel. Responden dalam penelitian ini adalah 100 Wisatawan Obyek Wisata Bukit Pentulu Indah . Penelitian ini menggunakan metode analisis deskriptif dan statistik yang dilakukan uji validitas, uji reliabilitas, uji multikolinieritas, uji heteroskedestitas, uji normalitas, uji korelasi, koefisien determinasi, uji $\mathrm{t}$, analisis jalur, dan uji ganda. Pengujian dalam uji t menunjukkan bahwa Attraction berpengaruh positif dan signifikan terhadap Visitor Satisfaction, Servicescape berpengaruh positif dan signifikan terhadap Visitor Satisfaction, Attraction berpengaruh positif dan sighnifikan terhadap Revisit Intention, Servicescape tidak berpengaruh terhadap Revisit Intention, Visitor Satisfaction memiliki pengaruh positif dan signifikan terhadap Revisit Intention, Visitor Satisfaction dapat memediasi antara Attraction dengan Revisit Intention, dan Visitor Satisfaction dapat memediasi Servicescape dengan Revisit Intention.
\end{abstract}

\section{Pendahuluan}

Peningkatan pendapatan dan kekuatan pembelian masyarakat serta kebutuhan untuk keluar dari rutinitas guna melakukan perjalanan refresing dan mendapatkan sensasi baru membuat masyarakat mencari pariwisata yang bisa digunakan sebagai sarana melepaskan stres. Ini membuat industri pariwisata di berbagai daerah mulai meningkat. Industri ini secara langsung berdampak pada ekonomi, sosial dan budaya (Gegel, 2006) Saat ini pariwisata telah mengalami perubahan tren di mana pergeseran minat wisatawan telah melahirkan wisata alam menuju wisata yang berkualitas serta bisa menjawab kemauan Wisatawan, pola yang tidak bisa hanya dinikmati oleh mencari sendiri, tetapi juga ingin yang baru dengan pengalaman yang tidak biasa seperti dekat dengan alam dan masyarakat. untuk menjawab persoalan demikian maka diharapkan pengelola obyek wisata sadar 
akan manfaat yang dirasakan. Hal tersebut harus diperhatikan oleh semua pelaku wisata, kususnya Obyek Wisata yang ada di Kabupaten Kebumen.

Obyek wisata di Kabupaten Kebumen harus diikuti dengan pengelolaan Obyek Wisata yang baik dan juga pengenalan kepada masyarakat secara efektif dan efisien. Apabila pengunjung obyek wisata meningkat, maka akan berdampak pada pendapatan yang bertambah sehingga tidak kesulitan dalam menutup biaya-biaya yang digunakan untuk operasional obyek wisata. Menurut Wardhani (2008) dalam proses pengembangan pariwisata pengelola harus memperhatikan unsur-unsur pariwisata, salah satu unsur yang sangat penting dalam dunia pariwisata adalah wisatawan. Karena obyek wisata yang menarik adalah obyek wisata yang di minati banyak wisatawan, sebaik apapun sarana dan prasarana dari suatu obyek wisata tetap tidak bisa dikatakan menarik apabila tidak banyak wisatawan yang tertarik untuk mengunjungi. Oleh karenanya sangat penting disusun sebuah strategi pemasaran yang tepat dalam meningkatkan minat berkunjung kembali (revisit intention) di Kabupaten Kebumen terutama dari faktor Daya tarik wisata (attraction) dan layanan fasilitas fisik (Servicescape) yang baik sehingga dapat membuat wisatawan merasa senang yang berdampak pada kepuasan wisatawan, yang nantinya juga diharapkan para wisatawan melakukan kunjungan ulang ketempat yang sama. Potensi tersebut diharapkan menjadi sebuah tantangan yang menggembirakan pula,yaitu pertumbuhan usaha dan ekonomi pariwisata yang meningkat. Dengan demikian perlu dipikirkan kebijaksanaan yang tepat dalam perencanaan pengelolaan pariwisata yang matang dan tepat sebagai suatu industri.

Pengelolaan pariwisata di Kabupaten Kebumen pada kenyataannya masih belum dilakukan secara optimal, oleh karena itu guna mendukung pengelolaan pariwisata yang lebih baik, Dinas Kebudayaan dan Pariwisata Kabupaten Kebumen perlu melakukan strategi baru untuk pengembangan pariwisata agar dapat dimanfaatkan untuk pembangunan pariwisata di Kabupaten Kebumen khususnya, begitu juga bagi pelaku Wisata yang perlu menyadari akan potensi-potensi wisata yang dipunyai. Sejalan dengan diberlakukannya otonomi daerah, memberikan kewenangan pengaturan pariwisata seluas-luasnya kepada daerah Kabupaten atau Kota untuk melakukan pembangunan pariwisata daerah, namun dalam pelaksanaannya masih banyak pembangunan fisik daya tarik wisata dilakukan dengan cara mengeksploitasi alam tanpa memperhatikan kelangsungan ekosistem yang ada serta kurang memperhatikan peta kekuatan pasar wisata.

Dalam masalah ini pengelola wisata harus benar-benar sadar, bukan hanya sekedar memanfaatkan tempat obyek wisata yang sudah ada tapi bagaimana para pengelola wisata dapat menjaga kelestarian lingkungan tanpa merusaknya serta mampu menjaga ciri khas suatu obyek wisata. Dengan memperhatian masalah tersebut diharapkan para wisatawan yang berkunjung akan merasakan kepuasan tersendiri dan diharapkan dapat meningkatkan wisatawan melakukan kunjungan ulang (revisit intention).

Menurut Ali (2015) para pakar dan praktisi marketing mengatakan kunjungan ulang (revisit intention) telah diangggap sebagai fenomena yang dinginkan dalam pemasaran. Seperti halnya fenomena yang terjadi saat ini, dimana wisatawan yang berkunjung di suatu obyek wisata akan kembali datang hanya untuk menyembuhkan kepenatan atau hiruk pikuk kebisingan kota. Menurut (Wibowo, 2016) adalah bentuk perilaku dari pengalaman kunjungan sebelumnya pada kualitas layanan tujuan di negara atau wilayah yang sama. Artinya seorang wisatawan melakukan kunjungan ulang karena factor dari pengalaman sebelumnya yang dirasakan seperti daya tarik dan fasilitas fisik yang memuaskan.

Dengan mengunjungi tempat-tempat wisata yang bernuansa alam, artinya seseorang secara tidak langsung ingin kembali ke alam dimana pikiran mereka akan terelaksasi, hal tersebut tidak terlepas dari kepuasan wisatawan yang merasakan kenyamanan keindahan daya tarik 
serta fasilitas fisik yang ada pada obyek wisata. Kabupaten Kebumen sangat terkenal dengan banyaknya objek wisata salah satunya adalah obyek wisata alam berupa perbukitan yang cukup terkenal dan diminati para wisatawan yaitu Bukit Pentulu indah. Fenomena ini terjadi ada pada pengunjung Obyek wisata alam Bukit Pentulu Indah Karangsambung. Kabupaten Kebumen sangat terkenal dengan banyaknya objek wisata salah satunya adalah obyek wisata alam berupa perbukitan yang cukup terkenal dan diminati para wisatawan yaitu Bukit Pentulu indah.

Obyek wisata Pentulu Indah di Karangsambung ini merupakan obyek wisata alam berupa perbukitan, masyarakat sekitar menyebut obyek wisata tersebut Pentulu Indah karena pentulu artinya gundukan/bukit dan jika kita diatas bukit kita akan melihat pemendangan yang indah maka obyek wisata tersebut dinamakan Pentulu Indah. Bukit Pentulu Indah atau sering disebut dengan bukit PI tepatnya terletak di Desa Dakah, Kecamatan Karangsambung, lokasinya tidak jauh dari LIPI sekitar 2 KM, Obyek wisata bukit Pentulu Indah menyajikan nuansa alam yang di dominasi hutan pinus yang rindang dengan suasana yang masih asri dan sejuk jauh dari keramaian kota sehingga pengunjung dapat merasa ketenangan ketika berada di tempat tersebut, pengunjung juga dapat melihat pemandangan yang lebih luas dengan naik ke rumah pohon. Meski hanya berketinggian tak lebih dari 300 meter diatas permukaan air laut namun pemandangan yang disajikan tak mengecewakan. Apalagi ketika pagi hari akan terlihat sunrise yang cantik dan Kabut-kabut tebal akan terlihat menaungi segenap lembah Sungai Luk Ulo, ini menjadi daya tarik tersendri bagi para wisatawan. Mereka sampai tidak menghiraukan lokasi yang cukup jauh untuk mengunjungi Obyek Wisata alam Pentulu indah, demi mendapatkan liburan yang mereka inginkan dan mendapatkan kepuasan tersendiri.

Untuk masuk dan menikmati semua pemandangan yang indah sebagai daya tarik wisatawan serta berbagai layanan fasilitas yang telah tersedia di Obyek wisata alam Pentulu indah, Wisatawan hanya cukup mengeluarkan Rp10.000 ribu rupiah per individu. Mungkin ini juga salah satu daya tarik selain panorama yang indah yang dapat dinikmati para wisatawan serta berbagai layanan fasilitas yang disediakan juga biaya yang sangat murah untuk semua kalangan dari para pelajar sampai dengan kalangan menengah ke bawah dan kalangan menengah ke atas. Sehingga dapat dilihat pada tabel jumlah pengunjung Obyek Wisata alam Pentulu Indah.

Tabel 1. Data Pengunjung

\begin{tabular}{llcccc}
\hline \multirow{2}{*}{ No } & \multirow{2}{*}{ Objek Wisata } & $\mathbf{4}$ Tahun \\
\cline { 2 - 5 } & & $\mathbf{2 0 1 6}$ & $\mathbf{2 0 1 7}$ & $\mathbf{2 0 1 8}$ & $\mathbf{2 0 1 9}$ \\
\hline 1 & Pentulu Indah & 82.780 & 97.554 & 110.200 & 115.800 \\
2 & Pantai Logending & 129.464 & 124540 & 122.521 & 111.090 \\
\hline \multicolumn{2}{l}{ Sumber: Wawancara langsung dengan } & pengelola wisata pentulu Indah
\end{tabular}

Dari tabel 1. diatas dapat dilihat bahwa rasio pengunjung dari tahun 2016 sampai dengan 2019 pengunjung wisata Pentulu Indah terus mengalami peningkatan. Dibandingkan dengan obyek wisata alam lainya yang justru mengalami penurunan pengunjung dari tahun ke tahun. Dari tabel berikut juga membuktikan bahwa fenomena saat ini yaitu wisatawan lebih suka mengunjungi tempat perbukitan berupa wisata alam yang mengandung nuansa hutan pinus serta pemandangan perbukitan yang masih asri dan pemandangan yang dapat memberikan daya tarik tersendiri. Fenomena tersebut juga ditambah dengan banyaknya para wisatawan menacari tempat dengan view yang bagus juga intagrammable. Untuk mempertahankan jumlah wisatawan dalam jangka beberapa tahun bukanlah hal mudah, mengingat persaingan yang sangat ketat sekarang ini. 
Dari fenomena tersebut Peneliti melakukan mini riset dengan menggunakan pertanyaan tertutup dan mengambil sampel responden sebanyak 30 responden. Hasil mini risat dapat dilihat dalam tabel sebagai berikut:

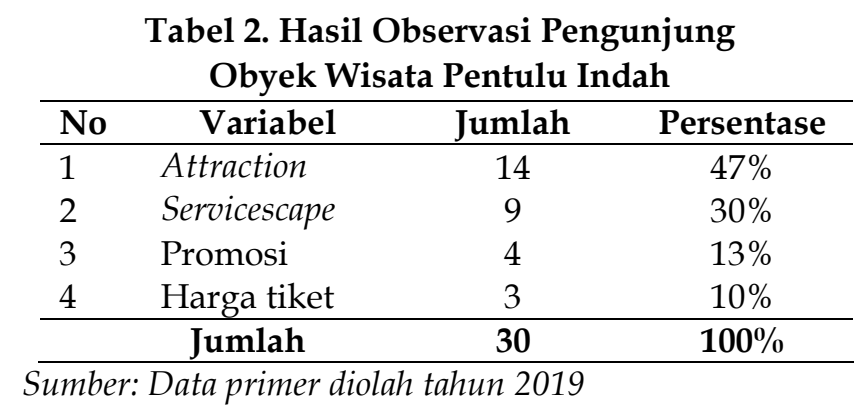

Berdasarkan tabel 2. survey awal dilakukan untuk 30 responden yang menjadi obyek penelitian bahwa 14 responden memimilih berkunjung ke tempat wisata karena attraction sebesar 40\%, 9 responden memilih tempat wisata kerena Servicescape sebesar 30\%, 4 responden memilih tempat wisata karena promosi sebesar $13 \%$, dan 3 responden memilih tempat wisata karena harga sebesar 10\%. Diantara pemilihan responden tersebut, terlihat bahwa serviscescape dan attraction mempunyai pengaruh yang besar dalam mengunjungi tempat wisata Bukit Pentulu Indah. Menjaga daya tarik objek wisata dan penambahan fasilitas harus terus dilakukan, dengan masih menjaga ciri khas dari Bukit Pentulu Indah, agar para pengunjung berminat untuk kembali berkunjung (revisit intention) ke tempat wisata Bukit Pentulu Indah.

Menurut Zeithaml et al. (2009), dalam (Deasy, 2012) revisit intention merupakan bentuk perilaku (behavioral intention) atau keinginan pelanggan untuk datang kembali, memberi word of mouth yang positif, tinggal lebih lama dari perikiraan, berbelanja lebih banyak dari perkiraan. Para wisatawan secara langsung dan tidak langsung membantu memasarkan objek wisata tersebut kepada keluarga, saudara, teman atau mungkin rekan kerja. Menggunakan sistem komunikasi yang dilakukan dari mulut ke mulut oleh para wisatawan sangat membantu untuk meningkatkan minat pengunjung.

Beberapa faktor yang dapat mempengaruhi kunjungan ulang yaitu kepuasan wisatawan, Menurut Kotler dan Keller (2016) dalam (Setyo Ferry Wibowo, 2016) kepuasan pelanggan adalah perasaan senang atau kecewa seseorang yang muncul setelah membandingkan persepsi atau kesan kinerja di bawah ini harapan, pelanggan tidak puas. Tapi, jika kinerjanya melebihi harapan, pelanggan sangat puas dan bahagia. Jika kinerja dirasakan di bawah ekspektasi, pelanggan akan merasa kecewa, jika kinerja bertemu harapan pelanggan, pelanggan akan merasa puas, sedangkan jika kinerjanya melebihi harapan, pelanggan akan rasakan Sangat Puas. Kepuasan ini akan tentu terasa setelah pelanggan masuk pertanyaan mengkonsumsi produk. Menurut Baker \& Crompton dalam Hsiu-Jung Chou (2013) kepuasan pengunjung merupakan pengalaman nyata dari wisatawan setelah mendapatkan pengalaman, yang berasal dari perasaan psikologis yang dihasilkan dari pengalaman individu dalam tujuan tempat wisata. Biasanya mereka menceritakan rasa senang dan kepuasan (visitor satisfaction) dengan keindahan sebagai daya tarik wisata (attraction) dan ketersedian layanan bentuk fisik (servicescape) yang memadai serta beberapa ciri khas yang ada sebagai daya tarik para wisatawan untuk berkunjung ke obyek wisata alam Bukit Pentulu Indah.

Faktor lain yang mempengaruhi minat berkunjung kembali yaitu daya tarik (attraction) menurut Yoeti (1985) daya tarik wisata atau tourist attraction merupakan istilah yang lebih sering digunakan, yaitu segala sesuatu yang menjadi daya tarik wisata untuk mengunjungi kembali suatu daerah tertentu. Menurut Ali (2011) Produk wisata merupakan sebuah paket yang tidak hanya tentang keindahan atau eksotisme suatu tempat wisata, tapi dalam arti yang lebih luas produk wisata mencakup daya tarik harga dalam saat berwisata dan juga akses 
menuju tempat wisata tersebut serta hal-hal lain yang berkaitan dengan daya tarik wisata. Daya tari yang di miliki Obyek Wisata Bukit Pentulu Indah yaitu Pemandangan alam yang indah dengan Perbukitan yang luas serta di selimuti oleh pohon-pohon pinus yang masih terjaga dengan baik, jika beruntung pada pagi hari akan terlihat sunrise dengan di temani kabut awan yang tebal seta terdapat rumah pohon untuk selfe dan hal unik lainya yang ada di Obyek wisata alam bukit pentulu indah.

Faktor berikutnya bentuk fisik (servicescape) menurut Bitner dan Gemler (2013) mendefinisikan servicescape sebagai semua fasilitas fisik organisasi yang dapat menjadi bentuk lain tangible communication. Servicescape merupakan fasilitas fisik organisasi yang digunakan untuk mempengaruhi perasaan konsumen agar senang dan positif. Menurut Zeithaml \& Bitner (2006:226) mengemukakan bahwa "Servicescape menggambarkan bagaimana lingkungan yang dibangun mempengaruhi baik konsumen maupun pegawai dalam sebuah industri jasa. Aspek-aspek dalam lingkungan fisik sendiri meliputi kondisi ambient ( temperatur udara, warna, music dan aroma wewangian), space/ fungtion (layout, perlengkapan ) dan simbol atau artifact". Obyek Wisata alam Bukit Pentulu Indah juga menyediakan beberapa fasilitas fisik seperti wahana permainan sederhana seperti flyingfok,motor roda tiga ,Panahan,dan mainan anak-anak lainya, ketersediaan layanan fasilitas umum seperti tempat ibadah, gazebo yang dapat digunakan untuk istirahat para pengunjung, toilet yang cukup memadai untuk memenuhi kebutuhan wisatawan, tempat parkir yang luas, jalan yang baik untuk di lewati dan terdapat warung penjual jajanan khas Kebumen serta tempat kuliner yang ada di kawasan Obyek Wisata Bukit Pentulu Indah.

Obyek Wisata Bukit Pentulu Indah selalu mengalami peningkatan wisatawan setiap tahunnya, apa lagi menjelang hari libur seperti liburan sekolah,taun baru dan pada saat hari Raya Idul Fitri. Obyek Wisata Bukit Pentulu Indah selalu dibanjiri para wisatawan dari lokal maupun luar daerah, meskipun dengan berbagai kesederhanaan yang ada akan tetapi banyak para wisatawan dari berbagai kalangan yang tertarik untuk kembali menikmati Obyek Wisata Bukit Pentulu Indah.

\section{Kajian Teori dan Telaah Literatur}

\section{Revisit Intention (Minat Berkunjung)}

Minat berkunjung ulang dalam penelitian ini disebut dengan (revisit intention) atau minat untuk kembali berkunjung yang merupakan minat seseorang untuk berkunjung kembali atau mengulangi suatu kegiatan terhadap suatu penyedia layanan/fasilitas. Sependapat dengan Fishbein dan Ajzen (1975) dalam Lin (2014) mendefinisikan revisit intention sebagai kemungkinan bagi wisatawan untuk bersedia mengulangi suatu kegiatan atau mengunjungi kembali fasilitas / tujuan. Selain itu, Hyunjin (2013:112) berpendapat minat mengunjungi kembali sebagai kemungkinan pelanggan menggunakan penyedia layanan berulang kali bahkan di masa depan sebagai kegiatan tindak lanjut dibuat setelah penggunaan selektif dari pelanggan.

Menurut Praminingsih dalam Pamela dan Pangemanan: (2015) minat mengunjungi kembali adalah niat untuk perencanaan dalam melakukan perilaku tertentu. Ketika orang memiliki niat yang kuat untuk terlibat dalam perilaku, mereka lebih menyukai untuk melakukan perilaku rekreasi pada sektor pariwisata, ini mengambil kembali pada layanan pariwisata atau layanan rekreasi atau kunjungan ulang dari tujuan atau pengunjung objek wisata. Minat mengunjungi kembali didefinisikan sebagai faktor penting untuk terus menciptakan 
keuntungan perusahaan atau kinerja dalam perspektif jangka panjang (Hyunjin, 2013:112). Menurut Kozak dalam Hyunjin (2013:112) minat mengunjungi kembali mengacu kepada kesediaan wisatawan untuk mengunjungi destinasi yang sama atau obyek wisata lain di negara yang sama. Dari penjelasan para ahli dapat disimpulkan bahwa minat berkunjung kembali (revisit intention) merupakan kesediaan atau minat seseorang untuk berkunjung kembali terhadap suatu tempat atau penyedia layanan yang sama atau yang lainnya di masa mendatang.

\section{Visitor Satisfaction (Kepuasan Pengunjung)}

Menurut Baker \& Crompton dalam Chou (2013) kepuasan pengunjung merupakan pengalaman nyata dari wisatawan setelah mendapatkan pengalaman, yang berasal dari perasaan psikologis yang dihasilkan dari pengalaman individu dalam tujuan tempat wisata. Biasanya mereka menceritakan rasa senang dan kepuasan (visitor satisfaction) dengan keindahan sebagai daya tarik wisata (attraction). Tjiptono (2005) mengemukakan bahwa kepuasan konsumen merupakan respon emosional terhadap pengalaman yang berkaitan dengan produk atau jasa yang dibeli. Selain itu, Kotler dan Keller (2016) dalam (Fitriani, 2017) berpendapat bahwa kepuasan pelanggan adalah perasaan senang atau kecewa seseorang yang muncul setelah membandingkan persepsi atau kesan kinerja dibawah harapan, pelanggan tidak puas. Tapi, jika kinerjanya melebihi harapan, pelanggan sangat puas dan bahagia. Jika kinerja dirasakan di bawah ekspektasi, pelanggan akan merasa kecewa, jika kinerja bertemu harapan pelanggan, pelanggan akan merasa puas, sedangkan jika kinerjanya melebihi harapan, pelanggan akan merasa sangat puas.

Suheri (2015) bahwa kepuasan pelanggan adalah keinginan, harapan dan kebutuhan pelanggan dapat menilai hasil jasa/pelayanan yang diberikan oleh pemberi jasa/pelayanan. Dimana hasil yang dihasilkan oleh pemberi jasa/pelayanan melebihi ekspektasi atau harapan pelanggan,maka dikatakan memuaskan, dan jika tidak melebihi ekspektasi,maka tidak mepuaskandanpelayanan tersebut dapat dipastikan tidak efektif dan efesien. Jika ingin mengembangkan suatu sistem, tingkat kepuasan pelanggan terhadap pelayanan merupakan faktor yang penting untuk memutuskan langkah ke depannya serta memperbaiki yang sudah ada.Terdapat berbagai definisi konseptual kepuasan pelanggan yang digunakan para peneliti sebelumnya. Menurut Giese dan Cote (2000) dalam penelitiannya telah mengidentifikasi berbagai definisi konseptual dari literatur dan dari para peneliti sebelumnya tentang kepuasan pelanggan. Berdasarkan beberapa definisi konseptual tersebut, Giese, dkk menyimpulkan tiga komponen utama dalam definisi kepuasan palanggan yaitu pertama kepuasan konsumen merupakan tanggapan emosional dan kognitif; kedua tanggapan lebih difokuskan pada ekspektasi, produk, konsumsi dan pengalaman; ketiga tanggapan terjadi setelah konsumsi, setelah pemilihan dan didasarkan pada akumulasi pengalaman. 


\section{Tourist Attraction (Daya Tarik)}

Menurut (Yoeti, 1985) daya tarik wisata atau tourist attraction merupakan istilah yang lebih sering digunakan, yaitu segala sesuatu yang menjadi daya tarik wisata untuk mengunjungi kembali suatu daerah tertentu. Menurut (Ali, 2015) Produk wisata merupakan sebuah paket yang tidak hanya tentang keindahan atau eksotisme suatu tempat wisata, tapi dalam arti yang lebih luas produk wisata mencakup daya tarik harga dalam saat berwisata dan juga akses menuju tempat wisata tersebut serta hal-hal lain yang berkaitan dengan daya tarik wisata.

Daya tarik wisata dapat berupa keunikan, keaslihan, cuaca/iklim, serta keindahan. Selain memiliki daya tarik, suatu obyek wisata alam akan lebih baik lagi, apabila terdiri dari beragam produk (diversivikasi) wisata. Semakin beragam produk akan semakin tertarik wisatawan mengunjunginya, tidak cepat bosan, cenderung memperpanjang waktu tinggal. Sejalan dengan bertambahnya lama tinggal akan meningkatkan pengeluarannya dan pada akhirnya akan meningkatkan kegiatan perkonomian lokal (Schawaighofer, 2014) dalam (Marpaung, 2019). Berdasarkan Undang-undang Republik Indonesia No.10 tahun 2009 menjelaskan bahwa daya tarik wisata adalah segala sesuatu yang memiliki keunikan, keindahan dan nilai yang berupa keanekaragaman kekayaan alam, budaya dan hasil buatan manusia yang menjadi sasaran atau kunjungan wisatawan. Menurut Nyoman (1994) dalam (Marpaung, 2019) mendefinisikan Daya Tarik Wisata sebagai segala sesuatu yang menarik dan bernilai untuk dikunjungi dan dilihat. Sedangkan menurut Yoeti (2002) menyatakan bahwa Daya Tarik Wisata atau tourism attraction ialah segala sesuatu yang menjadi daya tarik bagi orang untuk mengunjungi daerah wisata tertentu.

\section{Servicescape (Fasilitas Visik)}

Menurut Bitner dan Gemler (2013) mendefinisikan servicescape sebagai semua fasilitas fisik organisasi yang dapat menjadi bentuk lain tangible communication. Servicescape merupakan fasilitas fisik organisasi yang digunakan untuk mempengaruhi perasaan konsumen agar senang dan positif. Menurut Zeithaml \& Bitner (2006:226) mengemukakan bahwa (Servicescape) menggambarkan bagaimana lingkungan yang dibangun mempengaruhi baik konsumen maupun pegawai dalam sebuah industri jasa. Aspek-aspek dalam lingkungan fisik sendiri meliputi kondisi ambient (temperatur udara, warna, music dan aroma wewangian), space/ fungtion (layout, perlengkapan) dan simbol atau artifact.

Menurut Fitzsimmons (2011) servicescape adalah fasilitas fisik dalam layanan dirancang untuk kebutuhan tamu untuk mempengaruhi perilaku dan memuaskan para tamu di mana desain fasilitas fisik akan memiliki positif berdampak pada tamu dan karyawan. Sementara menurut Lovelock dan Wirtz (2011) dalam (Setyo Ferry Wibowo, 2016) servicescape adalah gaya dan bentuk lingkungan fisik dan lainnya elemen eksperimental yang ditemukan oleh pelanggan di mana layanan dikirimkan.

Menurut (Tjiptono, 2005) fasilitas adalah penyediaan perlengkapan-perlengkapan fisik untuk memberi kemudahan kepada konsumen untuk melaksanakan aktivitas-aktivitas sehingga kebutuhan konsumen dapat terpenuhi. Fasilitas merupakan penampilan, kemampuan sarana prasarana, dan keadaan lingkungan sekitarnya dalam menunjukkan eksistensinya kepada eksternal yang meliputi fasilitas fisik (gedung), perlengkapan dan peralatan (Lupioadi, 2008: 148). Sedangkan menurut Sulastiyono (dalam Nicklouse, 2015 : 1072) mengatakan bahwa 
fasilitas adalah penyediaan perlengkapan-perlengkapan fisik untuk memberikan kemudahan kepada para tamu dalam melaksanakan aktivitas-aktivitasnya atau kegiatan-kegiatannya, sehingga kebutuhan-kebutuhan tamu dapat terpenuhi. Jadi, dapat disimpulkan bahwa fasilitas adalah perlengkapan secara fisik yang disediakan pengelola objek wisata untuk mendukung dan memudahkan kegiatan aktivitas wisatawan saat berada di suatu objek wisata sehingga kebutuhan pengunjung terpenuhi. Fasilitas Pengembangan industri pariwisata membutuhkan fasilitas pariwisata yang mempunyai kaitan dan hubungan yang sangat luas dan dapat menggerakkan sektor-sektor lainnya dalam perekonomian suatu daerah. Fasilitas pariwisata dapat menentukan jumlah dan lama tinggal wisatawan, besar pengeluaran, dan pola penyebaran wisatawan dalam kawasan wisata. Perusahaan yang memberikan suasana menyenangkan dengan desain fasilitas yang menarik akan mempengaruhi konsumen dalam melakukan pembelian. Artinya bahwa salah satu faktor kepuasan konsumen dipengaruhi oleh fasilitas yang diberikan oleh penjual yang dimanfaatkan oleh konsumen sehingga mempermudah konsumen dalam proses pembelian. Berdasarkan pengertian di atas, maka dapat disimpulkan bahwa fasilitas wisata merupakan sarana pengunjung yang dapat menciptakan rasa menyenangkan yang disertai dengan kemudahan dan pemenuhan kebutuhan konsumen atau pengunjung dalam menimati produk atau jasa yang ditawarkan.

\section{Model Empiris}

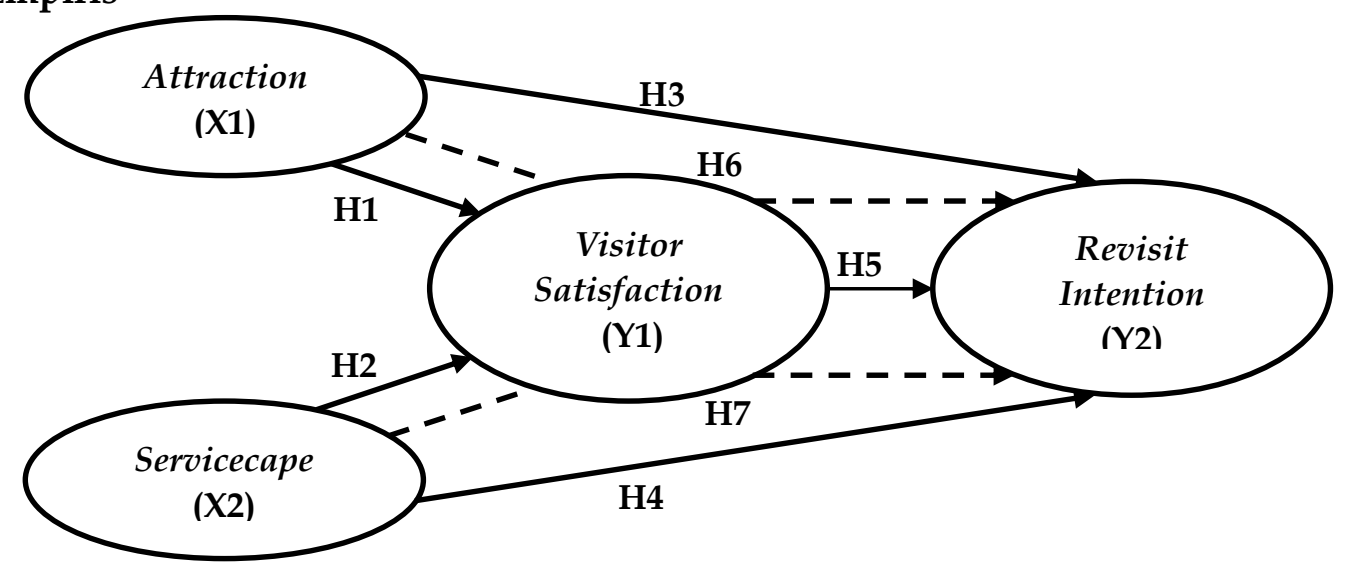

\section{Hipotesis}

Gambar 1. Konsep Model Empiris

Berdasarkan kerangka pemikiran diatas, maka hipotesis atau dugaan sementara yang diajukan dalam penelitian ini adalah sebagai berikut:

$\mathbf{H}_{\mathbf{1}} \quad$ : Terdapat pengaruh signifikan attraction terhadap visitor satisfaction wisatawan pada obyek Wisata Alam Pentulu Indah.

$\mathbf{H}_{\mathbf{2}} \quad$ : Terdapat pengaruh signifikan servicecape terhadap visitor satisfaction wisatawan pada obyek Wisata Alam Pentulu Indah.

$\mathbf{H}_{3} \quad$ : Terdapat pengaruh signifikan attraction terhadap revisit intention wisatawan pada obyek Wisata Alam Pentulu Indah.

$\mathbf{H}_{\mathbf{4}} \quad$ : Terdapat pengaruh singnifikan servicecape terhadap revisit intention wisatawan pada obyek Wisata Alam Pentulu Indah.

$\mathbf{H}_{5} \quad$ : Terdapat pengaruh signifikan visitor satisfaction terhadap revisit intention wisatawan pada obyek Wisata Alam Pentulu Indah.

$\mathbf{H}_{6} \quad$ : Terdapat pengaruh signifikan attraction terhadap revisit intention melalui visitor satisfaction sebagai variable intervening pada obyek Wisata Alam Pentulu Indah. 
$\mathbf{H}_{7} \quad$ : Terdapat pengaruh signifikan servicecape terhadap revisit intention melalui visitor satisfaction sebagai variable intervening pada obyek Wisata Alam Pentulu Indah.

\section{Metode Penelitian}

\section{Objek dan Subjek}

Objek penelitian yang digunakan adalah variabel dari servicescape, attraction sebagai variabel bebas (independent), dengan kepuasan (visitor satisfaction) sebagai variabel intervening dan minat berkunjung kembali (revisit intention) ke wisata Alam Bukit Pentulu Indah sebagai variabel terikat (dependent). Subjek pada penelitian ini adalah semua wisatawan yang pernah melakukan kunjungan ulang wisata di obyek wisata Alam Bukit Pentulu Indah lebih dari satu kali.

\section{Populasi dan Sampel}

Populasi dalam penelitian ini adalah wisatawan obyek pentulu indah yang sudah pernah berkunjung lebih dari satu kali. Menurut Sugiyono (2017:137) sampel penelitian adalah bagian jumlah dan karakteristik yang dimiliki oleh populasi yang menjadi subyek penelitian tersebut. Apabila populasi besar, dan peneliti tidak mungkin mempelajari semua yang ada pada populasi, misalnya karena keterbatasan dana, tenaga dan waktu, maka peneliti dapat menggunakan sampel yang diambil dari populasi itu. Secara umum ada dua jenis teknik pengambilan sampel, yaitu sampel acak atau random sampling/probability sampling, dan sampel tidak acak atau non random sampling/nonprobability sampling (Darmawan, 2014:144). Teknik yang digunakan dalam penelitian ini adalah nonprobability sampling.

Nonprobability sampling adalah teknik pengambilan sampel yang tidak diberi peluang/kesempatan bagi setiap unsur atau anggota populasi untuk dipilih menjadi sampel (Sugiyono, 2015:84). Teknik nonprobability sampling yang digunakan dalam penelitian ini adalah purposive sampling. Menurut Sugiyono (2015:84) Purposive sampling yaitu teknik penentuan sampel dengan pertimbangan tertentu. Kriteria atau pertimbangan yang diterapkan dalam pembagian kuesioner kepada responden adalah wisatawan obyek pentulu indah yang sudah pernah berkunjung lebih dari satu kali.

\section{Analisis Deskriptif}

Analisis Deskriptif yaitu analisis data dengan cara mendeskripsikan atau menggambarkan data yang telah terkumpul sebagaimana adanya tanpa bermaksud membuat kesimpulan yang berlaku untuk umum atau generalisasi. Penyajian data melalui tabel, grafik, diagram lingkaran dan lain-lain melalui perhitungan rata-rata dan standar deviasi, perhitungan persentase. Analisis deskiptif juga dapat dilakukan untuk mencari kuatnya hubungan antara variabel melalui analisis korelasi, melakukan prediksi dengan analisis regresi dan membuat perbandingan dengan membandingkan rata-rata dan sampel atau populasi (Sugiyono, 2010:148). 


\section{Analisis Kuantitatif}

Analisis data kuantitatif digunakan untuk menganalisis data dari hasil jawaban kuesioner dengan menggunakan metode-metode statistik. Analisis data kuantitatif ini menggunakan kuesioner sebagai alat bantu analisis yang berasal dari sampel sebanyak 100 responden yang pernah berkunjung di obyek wisata alam bukit pentulu indah. Adapun teknik analisis data dalam penelitian ini yaitu menggunakan pengujian validitas dan reabilitas dengan program SPSS ver.25.0.

\section{Uji Validitas dan Reliabilitas}

Uji validitas dalam sebuah penelitian digunakan untuk mengukur seberapa valid atau sah tidaknya suatu kuesioner. Kuesioner dikatakan valid apabila pertanyaan pada kuesioner mampu untuk mengungkapkan sesuatu yang akan diukur oleh kuesioner (Ghozali, 2005). Cara pengukuran validitas pada angket kmpetensi menggunakan teknik korelasi dengan "r pearson" atau koefisien korelasi "product moment pearson" dengan taraf signifikan 5\%. Sedangkan menurut Hadi (1991) untuk mengukur validitas kuesioner yang diberikan kepada responden digunakan rumus korelasi product moment sebagai berikut:

$$
r=\frac{n \sum x y-\left(\sum x\right)\left(\sum y\right)}{\sqrt{\left\{n \sum x^{2}-\left(\sum x\right)^{2}\right\}\left\{n \sum y^{2}-\left(\sum y\right)^{2}\right\}}}
$$

Reliabilitas adalah alat untuk mengukur suatu kuesioner yang merupakan indikator dari variabel atau konstruk (Ghozali, 2013). Kuesioner dinyatakan reliable atau handal apabila jawaban seseorang terhadap pernyataan selalu konsisten atau stabil dari waktu ke waktu. Suatu konstruk atau variabel dikatakan reliable jika statistik Cronbach Alpha $(\alpha)>0,60$ (Ghozali, 2005). Pengujian instrumen reliabilitas dilakukan menggunakan rumus Cronbach Alpha (Simamora, 2004) sebagai berikut:

$$
r_{11}=\left(\frac{k}{k-1}\right)\left(1-\frac{\sum \partial_{b^{2}}}{\partial_{t^{2}}}\right)
$$

\section{Uji Asumsi Klasik}

\section{a. Uji Normalitas}

Uji Normalitas bertujuan untuk menguji apakah dalam sebuah model regresi variabel terkait, variabel bebas atau keduanya mempunyai distribusi normal atau tidak. Suatu data berdistribusi normal dilihat dari penyebaran data (titik) pada sumbu diagonal dari grafik atau dengan melibatkan histogram dari residualnya, dasar pengambilan keputusan sebagai berikut (Ghozali, 2012):

1) Jika data menyebar di sekitar garis diagonal dan mengikuti arah garis diagonal, maka model regresi memenuhi normalitas;

2) Jika data menyebar jauh dari garis diagonal dan tidak mengikuti arah garis diagonal, maka model regresi tidak memenuhi normalitas.

\section{b. Uji Multikolinieritas}

Uji Multikolinearitas bertujuan untuk menguji apakah pada model regresi ditemukan adanya korelasi linear yang sempurna antar beberapa atau semua variabel bebas. Pengujian ini dilakukan untuk mendeteksi terdapat atau tidaknya multikolinearitas yaitu apabila 
korelasi antara dua variabel bebas lebih tinggi dibandingkan korelasi salah satu atau kedua variabel bebas tersebut dengan variabel terikat (Kuncoro, 2001). Menurut Ghozali (2012) cara mendeteksi terhadap adanya multikiilineritas dalam model regresi adalah sebagai berikut:

1) Besarnya variabele inflation factor (VIF), pedoman suatu model regresi yang bebas multikolineritas yaitu nilai $\leq 10$;

2) Besarannya tolerance pedoman sutau model regresi yang bebas Multikoneritas yaitu nilai tolerance $\geq 0,10$.

\section{c. Uji Heteroskedastisitas}

Pengujian ini dilakukan untuk menguji apakah dalam sebuah model regresi terjadi ketidaksamaan varian dan residual dari suatu pengamatan ke pengamatan yang lain. Jika variance dari residual satu pengamatan ke pengamatan lain tetap, maka disebut Homoskedastisitas dan jika berbeda disebut Heteroskedastisitas. Heteroskedastisitas muncul apabila kesalahan atau residual (e) dari model yang diamati tidak memiliki varian yang konstan dari suatu observasi ke observasi lainnya. Artinya, setiap observasi mempunyai reliabilitas yang berbeda akibat perubahan dalam kondisi yang melatarbelakangi tidak terangkum dalam spesifikasi model (Ghozali, 2005). Dasar analisis yang digunakan (Ghozali, 2005), adalah sebagai berikut:

1) Jika ada pola tertentu seperti titik yang ada membentuk pola tertentu yang teratur (bergelombang, melebar kemudian menyempit), maka mengidentifikasi telah terjadi heteroskedastisitas;

2) Jika tidak ada pola yang jelas, serta titik yang menyebar diatas dan dibawah angka nol sumbu Y, maka tidak terjadi heteroskedastisitas.

\section{Analisis Regresi Linier Berganda}

Analisis regresi adalah teknik statistika yang berguna untuk memeriksa dan memodelkan hubungan diantara variabel-variabel. Regresi berganda sering kali digunakan untuk mengatasi permasalahan analisis regresi yang mengakibatkan hubungan dari dua atau lebih variabel bebas. Model persamaan regresi linier berganda (Sugiyono, 2015) sebagai berikut:

$$
Y^{\prime}=a+b_{1} X_{1}+b_{2} X_{2}+b_{3} X_{3}+\ldots+b_{a} X_{a}
$$

\section{Uji Hipotesis}

\section{a. Uji Parsial (Uji t)}

Menurut Ghozali (2012) uji t digunakan untuk menguji signifikan hubungan antara variabel X dan Y, apakah variabel X1, X2, X3, (Produk, Harga dan Citra Merek) benar berpengaruh terhadap variabel $Y$ (Keputusan Pembelian) secara terpisah atau parsial. Uji $t$ digunakan untuk menguji secara parsial masing-masing variabel. Dalam penelitian ini hasil uji t dapat dilihat pada tabel coefficients pada kolom sig. dengan criteria:

1) Jika probabilitas $<0,05$, maka dapat dikatakan bahwa terdapat pengaruh antara variabel bebas terhadap variabel terikat secara parsial;

2) Jika probabilitas $>0,05$, maka dapat dikatakan bahwa tidak terdapat pengaruh antara variabel bebas terhadap variabel terikat secara parsial. 


\section{b. Uji Simultan (Uji F)}

Uji $F$ digunakan untuk menguji hubungan antara variabel $X$ dan apakah variabel $X 1, X 2, X 3$ (Pelatihan, Motivasi dan Kompensasi) benar-benar berpengaruh terhadap variabel $Y$ (Kinerja Karyawan) secara bersama sama (Ghozali,2012). Uji F digunakan untuk menguji salah satu hipotesis di dalam penelitian yang menggunakan analisis regresi linier berganda. Uji $\mathrm{F}$ digunakan untuk mengetahui pengaruh variabel bebas secara bersama-sama (simultan) terhadap variabel terikat. Hasil uji $\mathrm{F}$ dilihat dalam tabel ANOVA dalam kolom sig. dengan kriteria:

1) Jika nilai probabilitas $<0,05$, maka dapat dikatakan terdapat pengaruh yang signifikan secara bersama-sama antara variabel bebas terhadap variabel terikat;

2) Jika nilai probabilitas $>0,05$, maka tidak terdapat pengaruh yang signifikan secara bersama-sama antara variabel bebas terhadap variabel terikat.

\section{c. Koefisien Determinasi $\left(\mathbf{R}^{2}\right)$}

Koefisien determinasi $\left(\mathrm{R}^{2}\right)$ pada intinya mengukur seberapa jauh kemampuan model dalam menerangkan variasi variabel dependen. Nilai koefisien determinasi adalah antara nol dan satu. Nilai yang mendekati satu berarti variabel-variabel independen memberikan hampir semua informasi yang dibutuhkan untuk memprediksi variasi variabel dependen (Ghozali, 2018: 97). Nilai $\mathrm{R}^{2}$ dapat dicari dengan rumus:

$$
R^{2}=\frac{\mathrm{a} \Sigma \mathrm{y}+\mathrm{b} \Sigma \mathrm{xy}-\mathrm{n}(\mathrm{y})^{2}}{\Sigma \mathrm{y}^{2-} \mathrm{n}(\mathrm{y})^{2}}
$$

\section{Hasil dan Pembahasan}

\section{Analisis Deskriptif}

Karakteristik Responden Berdasarkan Domisili

Tabel 3. Klasifikasi Responden Berdasarkan Domisili

\begin{tabular}{lcc}
\hline \multicolumn{1}{c}{ Domisili } & Responden & Persentase \\
\hline $\begin{array}{l}\text { Kab. Kebumen } \\
\text { Luar Kab. }\end{array}$ & 63 & $63 \%$ \\
Kebumen & 37 & $37 \%$ \\
\hline \multicolumn{1}{c}{ Total } & 100 & $100 \%$ \\
\hline
\end{tabular}

Sumber: data primer yang diolah 2020

Berdasarkan tabel 3 diatas diketahui bahwa domisili responden pengunjung bukit Pentulu Indah Karangsambung dari Kab. Kebumen sebanyak 63 orang atau sebesar 63 \%, sedangkan responden dari luar Kab. Kebumen sebanyak 37 atau sebesar $37 \%$.

\section{Karakteristik Responden Berdasarkan Jenis Kelamin}

Tabel 4. Jenis Kelamin Responden

\begin{tabular}{lcc}
\hline Jenis Kelamin & Responden & Prosentase \\
\hline Laki-laki & 47 & $47 \%$ \\
Perempuan & 53 & $53 \%$ \\
\hline \multicolumn{1}{c}{ Jumlah } & $\mathbf{1 0 0}$ & $\mathbf{1 0 0} \%$ \\
\hline Sumber: Data Primer diolah, 2020. &
\end{tabular}


Berdasarkan tabel 4 diketahui bahwa responden pengunjung bukit Pentulu Indah Karangsambung dengan jenis kelamin laki - laki sebanyak 47 orang atau sebesar $47 \%$, responden dengan jenis kelamin perempuan sebanyak 53 atau sebesar $53 \%$.

\section{Karakteristik Responden Berdasarkan Usia}

\begin{tabular}{ccc} 
Tabel 5. Klasifikasi Responden Berdasarkan Usia \\
\hline Jenis Kelamin & Responden & Persentase \\
\hline $17-20$ & 20 & $20 \%$ \\
$21-30$ & 70 & $70 \%$ \\
$\geq 30$ & 10 & $10 \%$ \\
\hline Total & 100 & $100 \%$ \\
\hline
\end{tabular}

Sumber: data primer yang diolah 2020

Berdasarkan tabel 5 diatas diketahui bahwa responden pengunjung bukit Pentulu Indah Karangsambung dengan usia 17-20 tahun sebanyak 20 orang atau sebesar $20 \%$, responden dengan usia 21-30 tahun sebanyak 70 orang atau sebesar $70 \%$, responden dengan usia $\geq 30$ tahun sebanyak 10 orang atau sebesar $10 \%$.

\section{Karakteristik Responden Berdasarkan Tingkat Pendidikan}

Tabel 6. Klasifikasi Responden Berdasarkan Tingkat Pendidikan

\begin{tabular}{ccc}
\hline Jenis Kelamin & Responden & Persentase \\
\hline SD & 5 & $5 \%$ \\
SMP & 26 & $26 \%$ \\
SMA & 40 & $40 \%$ \\
Perguruan Tinggi & 29 & $29 \%$ \\
\hline Total & 100 & $100 \%$ \\
\hline Sumber: data primer yang diolah 2020 &
\end{tabular}

Sumber: data primer yang diolah 2020

Berdasarkan tabel 6 diatas diketahui bahwa responden pengunjung bukit Pentulu Indah Karangsambung dengan tingkat pendidikan SD sebanyak 5 orang atau sebesar $5 \%$, responden dengan tingkat pendidikan SMP sebanyak 26 orang atau sebesar $26 \%$, responden dengan tingkat pendidikan SMA sebanyak 40 orang atau sebesar $40 \%$, responden dengan tingkat pendidikan Perguruan Tinggi sebanyak 29 orang atau sebesar $29 \%$.

\section{Uji Validitas dan Reliabilitas}

\section{a. Variabel Attraction (X1)}

Tabel 7. Hasil Uji Variabel Attraction (X1)

\begin{tabular}{|c|c|c|c|c|}
\hline Variabel & Butir & R hitung & $R$ tabel & Ket \\
\hline \multirow{4}{*}{ Attraction } & 1 & 0,559 & 0,1966 & Valid \\
\hline & 2 & 0,684 & 0,1966 & Valid \\
\hline & 3 & 0,692 & 0,1966 & Valid \\
\hline & 4 & 0,636 & 0,1966 & Valid \\
\hline
\end{tabular}




\section{b. Variabel Servicescape (X2)}

Tabel 8. Hasil Uji Variabel Servicescape (X2)

\begin{tabular}{ccccc}
\hline Variabel & Butir & R hitung & R tabel & Ket \\
\hline \multirow{4}{*}{ Servicescape } & 1 & 0,710 & 0,1966 & Valid \\
& 2 & 0,818 & 0,1966 & Valid \\
& 3 & 0,740 & 0,1966 & Valid \\
\hline & 4 & 0,764 & 0,1966 & Valid \\
\hline
\end{tabular}

Sumber: Data Primer diolah, 2020

\section{c. Variabel Visitor Satisfaction (Y1)}

Tabel 9. Hasil Uji Variabel Visitor Satisfaction (Y1)

\begin{tabular}{ccccc}
\hline Variabel & Butir & R hitung & R tabel & Ket \\
\hline Visitor & 1 & 0,710 & 0,1966 & Valid \\
Satisfaction & 2 & 0,818 & 0,1966 & Valid \\
\multicolumn{5}{c}{ Sumber: Data Primer diolah, 2020 }
\end{tabular}

d. Variabel Revisit Iintention (Y2)

Tabel 10. Hasil Uji Variabel Revisit Intention (Y2)

\begin{tabular}{cclcc}
\hline Variabel & Butir & R hitung & R tabel & Ket \\
\hline Revisit & 1 & 0,760 & 0,1966 & Valid \\
Iintention & 2 & 0,885 & 0,1966 & Valid \\
& 3 & 0,844 & 0,1966 & Valid \\
\hline Sumber: Data Primer diolah, 2020 & &
\end{tabular}

Berdasarkan Tabel 7, 8, 9, dan 10 diatas dapat dijelaskan bahwa $\mathrm{r}$ hitung lebih besar dari $\mathrm{r}$ tabel $(0,1966)$ dengan nilai signifikansi sebesar $0,000<0,05$ sehingga semua item pertanyaan yang dipakai pada variabel Revisit Iintention dinyatakan valid.

\section{e. Uji Reliabilitas}

Tabel 11. Hasil Uji Reliabilitas

\begin{tabular}{lccc}
\hline \multicolumn{1}{c}{ Variabel } & $\mathbf{r}_{\text {kritis }}$ & $\boldsymbol{C A}$ & Ket \\
\hline Attraction & 0,60 & 0,689 & Reliabel \\
Servicescape & 0,60 & 0,750 & Reliabel \\
Visitor satisfaction & 0,60 & 0,777 & Reliabel \\
Revisit Intention & 0,60 & 0,775 & Reliabel \\
\hline Sumber: data primer diolah, 2020 & &
\end{tabular}

Berdasarkan tabel 11, menunjukkan bahwa empat instrumen yang digunakan dalam penelitian ini, memiliki nilai Cronbach's Alpha $>\mathrm{r}_{\text {kritis }}(0,60)$ sehingga dapat disimpulkan bahwa semua instrumen dalam penelitian dinyatakan reliable.

\section{Uji Asumsi Klasik}

\section{a. Multikolinearitas}

Tabel 12. Uji Multikolonieritas Substruktural 1

\begin{tabular}{ccccc}
\hline \multirow{2}{*}{ No } & \multirow{2}{*}{ Variabel } & \multicolumn{2}{c}{ Colinieritas Statistic } & \multirow{2}{*}{ Ket } \\
\cline { 3 - 4 } & & Tolerance & VIF & \\
\hline 1 & Attraction & 0,703 & 1,422 & Bebas Multikol \\
2 & Servicescape & 0,703 & 1,422 & Bebas Multikol \\
\hline \multicolumn{2}{c}{ Sumber: Data Primer diolah, 2020} & &
\end{tabular}


Tabel 13. Uji Multikolonieritas Substruktural 2

\begin{tabular}{clccc}
\hline \multirow{2}{*}{ No } & \multirow{2}{*}{ Variabel } & \multicolumn{2}{c}{ Colinieritas Statistic } & \multirow{2}{*}{ Ket } \\
\cline { 3 - 4 } & Tolerance & VIF & \\
\hline 1 & Attraction & 0,664 & 1,506 & Bebas Multikol \\
2 & Servicescape & 0,561 & 1,783 & Bebas Mutikol \\
3 & Visitor & 0,612 & 1,634 & Bebas Multikol \\
\hline & Satisfaction & & & \\
\hline
\end{tabular}

Sumber: data primer diolah, 2020

Berdasarkan tabel 12 dan 13, menunjukkan bahwa hasil uji multikolonieritas substruktural 2, dengan variabel bebas yaitu Attraction, Servicescape dan Visitor satisfaction mempunyai nilai tolerence $>0,1$ dan nilai VIF (Variance Inflaction Factor) $<10$, sehingga dapat disimpulkan bahwa tidak terjadi gejala multikolonieritas antar variabel bebas.

\section{b. Uji Heteroskedastisitas}

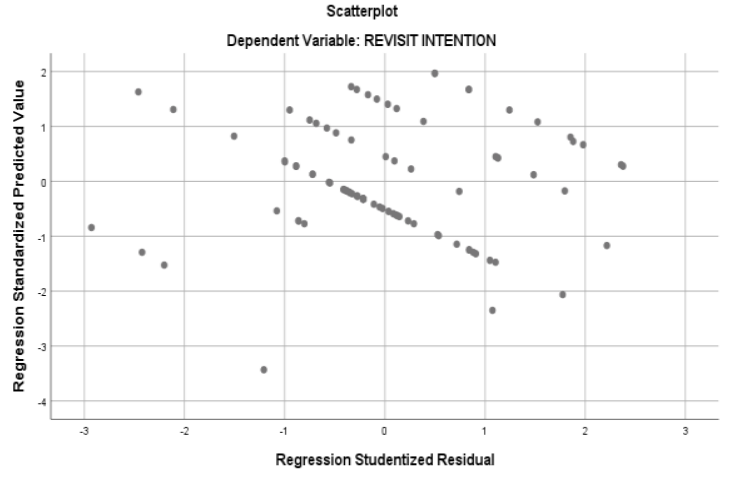

Gambar 2. Hasil Uji Substruktural I

Sumber:data primer diolah, 2020

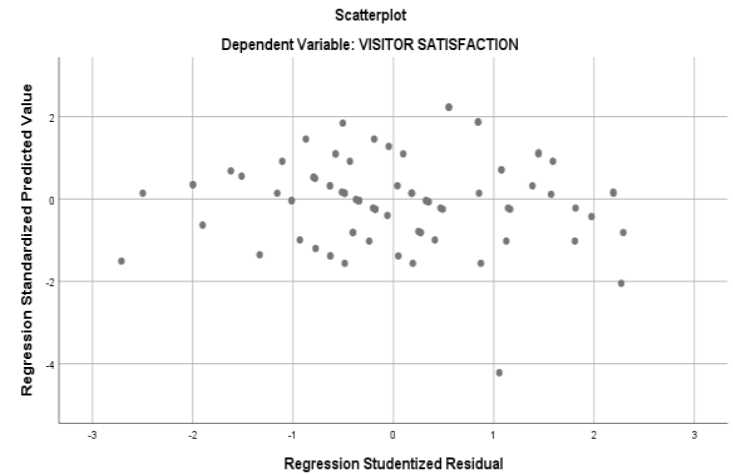

Gambar 3. Hasil Uji Substruktural 2

Sumber:data primer diolah, 2020

Gambar 2 dan 3 scatterplot menunjukkan bahwa semua data menyebar dan tidak membentuk pola tertentu. Sehingga dapat disimpulkan bahwa semua variabel peneitian tersebut terbebas dari gejala heterokedastisitas.

\section{c. Uji Normalitas}

Gambar 4. Hasil Uji Substruktural 1

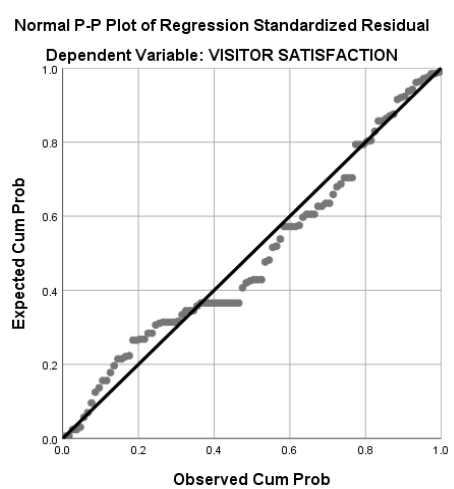

Sumber:data primer diolah, 2020

\section{Gambar 5. Hasil Uji Substruktural 1}

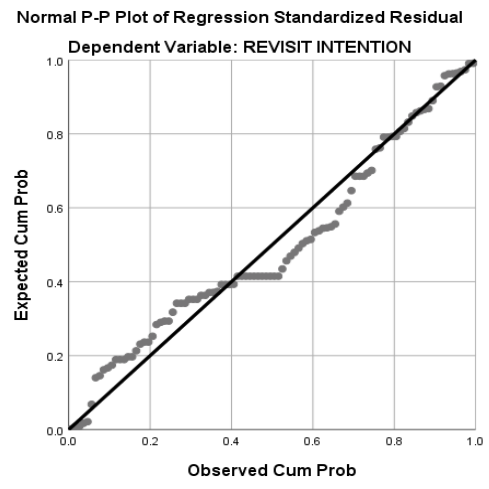

Sumber:data primer diolah, 2020 
Berdasarkan gambar 4 dan 5, penyebaran titik-titik disekitar garis diagonal dan penyebaran mengikuti garis diagonal. Jadi variabel terikat dan variabel bebas dalam penelitian ini normal.

\section{Uji Hipotesis}

\section{a. Uji Parsial (Uji t)}

Tabel 14. Hasil Uji t Substruktural I Coefficients $^{\mathrm{a}}$

\begin{tabular}{llcc}
\hline Model & $\mathrm{t}$ & Sig. \\
\hline 1 (Constant) & 4,198 & .000 \\
& Attraction & 2.389 & .019 \\
& Serviscescape & 4.960 & .000 \\
\hline
\end{tabular}

a. Dependent Variable: Visitor Satisfaction

Sumber : data primer diolah, 2020

Berdasarkan tabel 14. tersebut hasil uji parsial (uji t) dapat dianalisis sebagai berikut:

1) Hasil uji t pada tabel 14 diatas, menujukan bahwa probabilitas signifikan variabel Attraction (X1) sebesar 0,019 < 0,05 dan hasil perhitungan diperoleh angka $t_{\text {hitung }}$ sebesar 2,389 > 1,984. Hasil ini menyatakan bahwa variabel Attraction mempunyai pengaruh positif dan signifikan terhadap Visitor Satisfaction di Obyek wisata bukit Pentulu Indah.

2) Hasil uji t pada tabel 14 diatas, menujukan bahwa probabilitas signifikan variabel Servicescape (X2) sebesar 0,000 $<0,05$ dan hasil perhitungan diperoleh angka $t_{\text {hitung }}$ sebesar 4,960>1,984. Hasil ini menyatakan bahwa variabel Servicescape mempunyai pengaruh positif dan signifikan terhadap Visitor Satisfaction di Obyek wisata bukit Pentulu Indah.

Tabel 15. Hasil Uji t Substruktural II Coefficients ${ }^{a}$

\begin{tabular}{llrr}
\hline \multicolumn{2}{l}{ Model } & $\mathrm{t}$ & \multicolumn{1}{l}{ Sig. } \\
\hline 1 & (Constant) & -2.996 & .003 \\
& Attraction & 2.679 & .009 \\
& Servicescape & -.417 & .677 \\
& Visitor Satisfaction & 7.411 & .000 \\
\hline
\end{tabular}

a. Dependent Variable: Revisit Intention

Sumber : data primer diolah, 2020

Berdasarkan tabel 15 tersebut hasil uji parsial (uji t) dapat dianalisis sebagai berikut:

1) Hasil uji t pada tabel 15 diatas, menujukan bahwa probabilitas signifikan variabel Attraction (X1) sebesar 0,009 $<0,05$ dan hasil perhitungan diperoleh angka $t_{\text {hitung }}$ sebesar 2,679 > 1,984. Hasil ini menyatakan bahwa variabel Attraction mempunyai pengaruh positif dan signifikan terhadap Revisit Intention di Obyek wisata bukit Pentulu Indah.

2) Hasil uji t pada tabel 15 diatas, menujukan bahwa probabilitas signifikan Servicescape (X2) sebesar 0,677 > 0,05 dan hasil perhitungan diperoleh angka $t_{\text {hitung }}$ sebesar -0,417 $<1,984$. Hasil ini menyatakan bahwa variabel Servicescape tidak mempunyai pengaruh terhadap Revisit Intention di Obyek wisata bukit Pentulu Indah. 
3) Hasil uji t pada tabel 15 diatas, menujukan bahwa probabilitas signifikan variabel Visitor Satisfaction (Y1) sebesar 0,000 $<0,05$ dan hasil perhitungan diperoleh angka

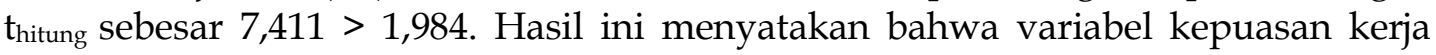
mempunyai pengaruh positif dan signifikan terhadap Revisit Intention di Obyek wisata bukit Pentulu Indah.

\section{b. Koefisien Determinasi $\left(\mathbf{R}^{2}\right)$}

Tabel 16. Hasil Uji Koefisien Determinasi Substruktural I

Model Summary ${ }^{b}$

\begin{tabular}{cccc}
\hline Model & $\mathrm{R}$ & R Square & Adjusted R Square \\
\hline 1 & $.623^{\mathrm{a}}$ & .388 & .375 \\
\hline
\end{tabular}

a. Predictors: (Constant), Attraction dan Servicescape

b. Dependent Variable: Visitor Satisfaction

Sumber : data primer diolah, 2020

Berdasarkan tabel 16, hasil pengujian ini menunjukkan bahwa nilai Adjusted $R^{2}$ substruktural 1 sebesar 0,375 artinya sebesar 37,5\% variabel Visitor Satisfaction dapat dijelaskan oleh variabel Attraction dan Servicescape, sedangkan sisanya 62,5\% dapat dijelaskan oleh variabel lain yang tidak ada dalam model penelitian ini.

\section{Tabel 17. Hasil Uji Koefisien Determinasi Substruktural II Model Summary ${ }^{\mathrm{b}}$

\begin{tabular}{cccc}
\hline Model & $\mathrm{R}$ & R Square & Adjusted R Square \\
\hline 1 & $.749^{\mathrm{a}}$ & .561 & .547
\end{tabular} \\ a. Predictors: (Constant), Attraction dan \\ Servicescape, Visitor Satisfaction \\ b. Dependent Variable: Revisit Intention \\ Sumber : data primer diolah, 2020}

Berdasarkan tabel IV-15, hasil pengujian ini menunjukkan bahwa nilai Adjusted $R^{2}$ substruktural 2 sebesar 0,547 artinya sebesar 54,7\% variabel Revisit Intention dapat dijelaskan oleh variabel Attraction, Servicescape dan Visitor Satisfaction sedangkan sisanya 45,3\% dapat dijelaskan oleh variabel lain yang tidak ada dalam model penelitian ini.

\section{Analisis Korelasi}

Tabel 18. Hasil Uji Korelasi

Correlations

\begin{tabular}{llcr}
\hline & Attraction (X1) Servicescape (X2) \\
\hline X1 & Pearson Correlation & 1 & $.545^{* *}$ \\
Sig. (2-tailed) & 100 & .000 \\
N & $.545^{* *}$ & 100 \\
X2 Pearson Correlation & .000 & 1 \\
& Sig. (2-tailed) & 100 & 100 \\
$\quad \mathrm{~N}$ & \\
**. Correlation is significant at the 0.01 level (2-tailed). & \\
Sumber : Data primer diolah, 2020 &
\end{tabular}


Berdasarkan hasil analisis korelasi pada tabel 18. Dapat disimpulkan bahwa hubungan Attraction terhadap Servicescape memiliki nilai sebesar 0,545 sehingga dapat dikatakan memiliki korelasi yang kuat.

\section{Sobel Test}

a. Pengaruh Attraction terhadap Revisit Intention melalui Visitor Satisfaction.

Tabel 19. Hasil Uji Sobel Struktural I

\begin{tabular}{ccc}
\hline Test Statistic & Standar Error & P-Value \\
\hline 2.27610594 & 0.04342153 & 0.02283967 \\
\hline
\end{tabular}

b. Pengaruh Servicescape terhadap Revisit Intention melalui Visitor Satisfaction.

Tabel 20. Hasil Uji Sobel Sruktural II

\begin{tabular}{ccc}
\hline Test Statistic & Standar Error & P-Value \\
\hline 4.12444985 & 0.05152493 & 0.00003716 \\
\hline
\end{tabular}

Berdasarkan Tabel 19 dan 20, menunjukkan bahwa hasil test statistic $>t_{\text {tabel }}$ dan $p$-value $<a$. Maka dapat dikatakan bahwa visitor satisfaction dapat memediasi attraction dan servicescape terhadap revisit intention.

\section{Analisis Jalur}

a. Pengaruh Langsung (Direct Effect atau DE)

Cara untuk menghitung pengaruh langsung atau disebut juga DE, digunakan formula sebagai berikut:

1) Pengaruh variabel Attraction terhadap Visitor Satisfaction.

$$
\mathrm{X}_{1} \rightarrow \mathrm{Y}_{1}=0,226
$$

2) Pengaruh variabel Servicescape terhadap Visitor Satisfaction.

$\mathrm{X}_{2} \rightarrow \mathrm{Y}_{1}=0,470$

3) Pengaruh variabel Attraction terhadap Revisit Intention.

$\mathrm{X}_{1} \rightarrow \mathrm{Y}_{2}=0,222$

4) Pengaruh variabel Servicescape terhadap Revisit Intention.

$\mathrm{X}_{2} \rightarrow \mathrm{Y}_{2}=-0,038$

5) Pengaruh variabel Visitor Satisfaction terhadap Revisit Intention.

$\mathrm{Y}_{1} \rightarrow \mathrm{Y}_{2}=0,641$

\section{b. Pengaruh Tidak Langsung (indirect effect)}

Cara untuk menghitung pengaruh tidak langsung atau IE, digunakan formula sebagai berikut.

1) Pengaruh variabel Attraction terhadap Revisit Intention. melalui Visitor Satisfaction. $\mathrm{X}_{1} \rightarrow \mathrm{Y}_{1} \rightarrow \mathrm{Y}_{2}=0,226 \times 0,641=0,145$

2) Pengaruh variabel Servicescape terhadap Revisit Intention. melalui Visitor Satisfaction $\mathrm{X}_{2} \rightarrow \mathrm{Y}_{1} \rightarrow \mathrm{Y}_{2}=0,470 \times 0,641=0,301$

c. Pengaruh Total (total effect)

1) Pengaruh variabel Attraction terhadap Revisit Intention. melalui Visitor Satisfaction. $\mathrm{X}_{1} \rightarrow \mathrm{Y}_{1} \rightarrow \mathrm{Y}_{2}=0,226+0,641=0,867$

2) Pengaruh variabel Servicescape terhadap Revisit Intention melalui Visitor Satisfaction. $\mathrm{X}_{2} \rightarrow \mathrm{Y}_{1} \rightarrow \mathrm{Y}_{2}=0,470+0,641=1,111$

3) Pengaruh variabel Attraction terhadap Revisit Intention. 
$\mathrm{X}_{1} \rightarrow \mathrm{Y}_{2}=0,222$

4) Pengaruh variabel Servicescape terhadap Revisit Intention.

$\mathrm{X}_{2} \rightarrow \mathrm{Y}_{2}=-0,038$

5) Pengaruh variabel Visitor Satisfaction terhadap Revisit Intention

$\mathrm{Y}_{1} \rightarrow \mathrm{Y}_{2}=0,641$

\section{Diagram Jalur}

Berikut adalah hasil analisis jalur yang dapat digunakan untuk menggambar diagram jalur yang dikembangkan dalam model penelitian ini, yaitu:

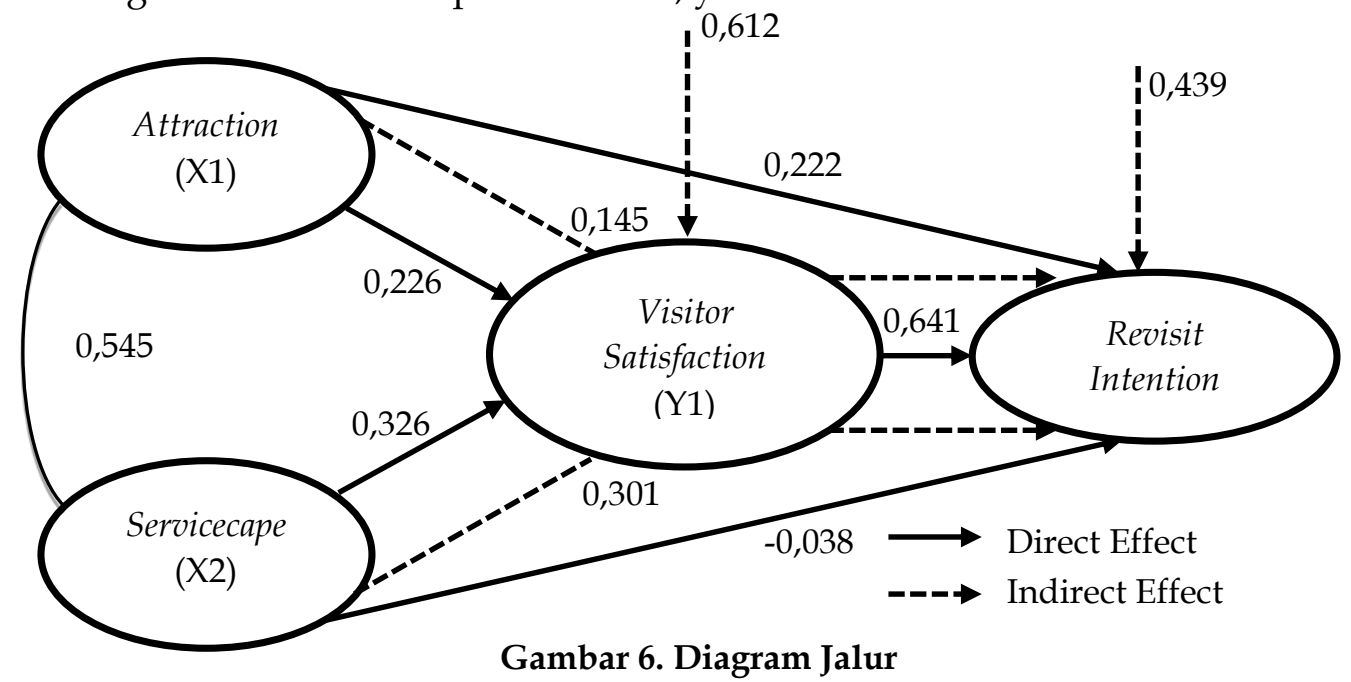

Persamaan struktural model untuk Gambar IV-5 tersebut adalah:

Substruktural 1: Y1 $=0,226 \mathrm{X} 1+0,470 \mathrm{X} 2+0,612$

Substruktural 2: Y2 = 0,222 X1 - 0,038 X2+ 0,641 Y1+ 0,439

\section{Pembahasan}

Penelitian ini bertujuan untuk mengetahui seberapa besar pengaruh variabel bebas (Attraction dan servicescape) terhadap variabel terikat (revisit Intention) dengan Visitor Satisfaction sebagai variabel intervening. Implikasi yang disarankan dalam penelitian ini adalah sebagai berikut:

\section{Pengaruh Attraction terhadap Visitor Satisfaction.}

Berdasarkan hasil analisis dan pembahasan diatas terbukti bahwa hipotesis attraction berpengaruh positif dan signifikan terhadap visitor satisfaction karena nilai thitung sebesar 2.389 $>t_{\text {tabel }}$ sebesar 1,984, maka H1 diterima. Besarnya pengaruh attraction terhadap visitor satisfaction sebesar 0,019 $<0,05$ artinya attraction berpengaruh signifikan terhadap Visitor Satisfaction. Berdasarkan jawaban responden yang diperoleh dari hasil kuesioner menunjukan bahwa sebagian besar responden memberikan penilaian yang tinggi terhadap variabel attraction. Hal ini membuktikan bahwa saran yang diberikan variabel attraction mampu mempengaruhi visitor satisfaction wisatawan Obyek Wisasa Bukit Pentulu Indah. Artinya, semakin tinggi attraction pada Obyek Wisasa Bukit Pentulu Indah maka akan meningkatkan visitor satisfaction wisatawan. Hal ini berarti bahwa apabila perceived organizational support ditingkatkan, maka visitor satisfaction wisatawan juga akan mengalami peningkatan. Citra pariwisata, Akses menuju lokasi, serta harga pada Obyek wisata Bukit Pentulu Indah mampu 
meningkatkan kepuasan wisatawan Obyek Wisasa Bukit Pentulu Indah. Hasil penelitian ini mendukung penelitian yang dilakukan oleh Sopyan (2015) yang menyatakan bahwa attraction terbukti berpengaruh secara postif dan signifikan terhadap visitor satisfaction. Adjusted $R$ Square substruktur I sebesar 0,375 artinya variansi dari variabel intervening dapat dijelaskan oleh varibel independen sebesar $37,5 \%$ sehingga koefisien pengaruh variabel lain tidak diteliti dalam penelitian ini adalah sebesar $62,5 \%$.

\section{Pengaruh Servicescape terhadap Visitor Satisfaction}

Berdasarkan hasil analisis dan pembahasan diatas terbukti bahwa hipotesis servicescape berpengaruh positif dan signifikan terhadap visitor satisfaction karena nilai $t_{\text {hitung }}$ sebesar 4,960 $>t_{\text {tabel }}$ sebesar 1,984 maka H2 diterima. Besarnya pengaruh serviscescape terhadap visitor satisfaction sebesar 0,000 $<0,05$ artinya serviscescape berpengaruh signifikan terhadap visitor satisfaction. Berdasarkan jawaban responden yang diperoleh dari hasil kuesioner menunjukan bahwa sebagian besar responden memberikan penilaian yang tinggi terhadap variabel servicescape. Hal ini membuktikan bahwa saran yang diberikan variabel servicescape mampu mempengaruhi visitor satisfaction wisatawan Obyek Wisasa Bukit Pentulu Indah. Artinya, semakin baik serviscescape atau vasilitas yang ada di Obyek Wisata Bukit pentulu Indah maka akan meningkatkan visitor satisfaction pada Wisatawan Obyek Wisata Pentulu Indah. Ketersediaan tempat parkir, tersedianya fasilitas umum, dan tempat kuliner di Obyek Wisata Pentulu Indah mampu mempengaruhi visitor satisfaction wisatawan. Hasil penelitian ini mendukung penelitian yang dilakukan oleh Michael, Shenjry (2014) bahwa terdapat pengaruh yang positif dan signifikan antara Serviscescape dan Visitor Satisfaction. Semakin baik serviscescape maka semakin tinggi pula visitor satisfaction. Adjusted $R$ Square substruktur I sebesar 0,375 artinya variansi dari variabel intervening dapat dijelaskan oleh varibel independen sebesar 37,5\% sehingga koefisien pengaruh variabel lain tidak diteliti dalam penelitian ini adalah sebesar $62,5 \%$.

\section{Pengaruh Attraction terhadap Revisit Intention}

Berdasarkan hasil analisis dan pembahasan diatas terbukti bahwa hipotesis attraction berpengaruh positif dan sighnifikan terhadap revisit intention karena nilai $t_{\text {hitung }}$ sebesar 2,679 $>t_{\text {tabel }}$ sebesar 1,984 maka h3 diterima. besarnya pengaruh attraction terhadap revisit intention sebesar 0,009 < 0,05 artinya attraction berpengaruh sighnifikan terhadap revisit intention. Berdasarkan jawaban responden yang diperoleh dari hasil kuesioner menunjukan bahwa sebagian besar responden memberikan penilaian yang tinggi terhadap variabel attraction. Hal ini membuktikan bahwa saran yang diberikan variabel attraction mampu mempengaruhi revisit intention wisatawan Obyek Wisasa Bukit Pentulu Indah. Artinya, semakin baik attraction atau daya Tarik pada Obyek Wisata Bukit pentulu Indah maka semakin tinggi pula revisit intention pada Wisatawan Obyek Wisata Pentulu Indah. Citra pariwisata, Akses menuju lokasi, serta harga pada Obyek wisata Bukit Pentulu Indah mampu meningkatkan minat berkunjung kembali wisatawan Obyek Wisasa Bukit Pentulu Indah. Hasil penelitian ini mendukung penelitian yang dilakukan Sopyan (2015) yang menyatakan bahwa terdapat pengaruh yang positif dan sighnifikan Attraction dengan Revisit Intention. Hal ini berarti bahwa semakin tinggi Attraction maka akan meningkatkan Revisit Intention. Adjusted R Square substruktur II sebesar 0,547 artinya variansi dari variabel intervening dapat dijelaskan oleh varibel independen sebesar $54,7 \%$ sehingga koefisien pengaruh variabel lain tidak diteliti dalam penelitian ini adalah sebesar $45,3 \%$. 


\section{Pengaruh Servicescape terhadap Revisit Intention}

Berdasarkan hasil analisis dan pembahasan diatas terbukti bahwa hipotesis servicescape tidak memiliki pengaruh terhadap revisit intention karena nilai $t_{\text {hitung }}$ sebesar $-0,417<t_{\text {tabel }}$ sebesar 1,984 maka h4 ditolak. besarnya pengaruh servicescape terhadap revisit intention sebesar 0,677 $>0,05$ artinya servicescape tidak memiliki pengaruh terhadap revisit intention. Hal ini membuktikan bahwa saran yang diberikan variabel servicescape tidak mampu mempengaruhi revisit intention wisatawan Obyek Wisasa Bukit Pentulu Indah. Artinya, serviscescape atau vasilitas yang ada di Obyek Wisata Bukit pentulu Indah tidak mampu meningkatkan revisit intention Wisatawan Obyek Wisata Pentulu Indah. Ketersediaan tempat parkir, tersedianya fasilitas umum, dan tempat kuliner di Obyek Wisata Pentulu Indah tidak mampu mempengaruhi revisit intention wisatawan. Hasil penelitian ini tidak mendukung penelitian yang dilakukan oleh Setya (2011) bahwa terdapat pengaruh yang positif dan signifikan Servicescape dan Revisit Intention. Adjusted $R$ Square substruktur II sebesar 0,547 artinya variansi dari variabel intervening dapat dijelaskan oleh varibel independen sebesar 54,7\% sehingga koefisien pengaruh variabel lain tidak diteliti dalam penelitian ini adalah sebesar 45,3\%.

\section{Pengaruh Visitor Satisfaction terhadap Revisit Intention}

Berdasarkan hasil analisis dan pembahasan diatas terbukti bahwa hipotesis visitor satisfaction berpengaruh positif dan signifikan terhadap revisit intention karena nilai $t_{\text {hitung }}$ sebesar 7,411 > $t_{\text {tabel }}$ sebesar 1,984, maka h5 diterima. besarnya pengaruh visitor satisfaction terhadap revisit intention sebesar 0,000 $<0,05$ artinya visitor satisfaction berpengaruh positif dan signifikan terhadap revisit intention. hal ini berarti semakin tinggi visitor satisfaction maka akan meningkatkan revisit intention pada Wisatawan Bukit pentulu Indah. Berdasarkan jawaban responden yang diperoleh dari hasil kuesioner menunjukan bahwa sebagian besar responden memberikan penilaian yang tinggi terhadap variabel visitor satisfaction. Hal ini membuktikan bahwa saran yang diberikan variabel visitor satisfaction mampu mempengaruhi revisit intention wisatawan Obyek Wisasa Bukit Pentulu Indah. Artinya, semakin baik visitor satisfaction wisatawan pada Obyek Wisata Bukit pentulu Indah maka semakin tinggi pula revisit intention. Citra pariwisata, Akses menuju lokasi, serta harga pada Obyek wisata Bukit Pentulu Indah mampu meningkatkan minat berkunjung kembali wisatawan Obyek Wisasa Bukit Pentulu Indah. Kepuasan general atau kepuasan keseluruhan yang dirasakan oleh wisatawan, kesesuaian harapan terhadap persepsi dari wisatawan, serta kepuasan dari perbandingan situasi yang ideal dari wisatawan mampu mempengaruhi minat berkunjung kembali wisatawan Obyek Wisasa Bukit Pentulu Indah. Hasil penelitian ini mendukung penelitian yang dilakukan oleh Sopyan (2015) bahwa Visitor Satisfaction berpengaruh positif dan signifikan terhadap Revisit Intention. Artinya, semakin tinggi visitor satisfaction maka akan dapat meningkatkan revisit intention. Adjusted R Square substruktur II sebesar 0,547 artinya variansi dari variabel intervening dapat dijelaskan oleh varibel independen sebesar 54,7\% sehingga koefisien pengaruh variabel lain tidak diteliti dalam penelitian ini adalah sebesar $45,3 \%$.

\section{Pengaruh Attraction terhadap Revisit Intention Melalui Visitor Satisfaction}

Berdasarkan hasil analisis dan pembahasan diatas terbukti bahwa hipotesis pengaruh attraction terhadap revisit intention dengan visitor satisfaction sebagai variabel intervening yaitu dengan melihat hasil uji sobel pada struktural i menunjukkan bahwa variabel visitor satisfaction berfungsi sebagai variabel intervening karena test statistic $>t_{\text {tabel }}$ yaitu 2.27610594 
$>1,98447$ dan $p$-value < a yaitu $0.00003716<0,05$. hal ini menunjukkan bahwa visitor satisfaction dapat menjadi variabel intervening attraction terhadap revisit intention. artinya bahwa attraction yang baik dapat mempengaruhi visitor satisfaction yang nantinya akan berpengaruh pada revisit intention obyek wisata bukit pentulu indah . jika attraction yang dirasakan oleh wisatawan semakin baik maka visitor satisfaction akan tinggi. dengan demikian, visitor satisfaction yang tinggi tentu akan membuat revisit intention Obyek wisata Bukit Pentulu Indah juga akan semakin meningkat.

\section{Pengaruh Servicescape terhadap Revisit Intention melalui Visitor Satisfaction}

Berdasarkan hasil analisis dan pembahasan diatas terbukti bahwa hipotesis pengaruh servicescape terhadap revisit intention dengan visitor satisfaction sebagai variabel intervening yaitu dengan melihat hasil uji sobel pada struktural ii menunjukkan bahwa variabel visitor satisfaction berfungsi sebagai variabel intervening karena test statistic $>t_{\text {tabel }}$ yaitu $4.12444985>$ 1,98447 dan $p$-value $<a$ yaitu $0.0003716<0,05$. hal ini menunjukkan bahwa visitor satisfaction dapat menjadi variabel intervening servicescape terhadap revisit intention. artinya bahwa servicescape yang baik dapat mempengaruhi visitor satisfaction yang nantinya akan berpengaruh pada revisit intention Obyek Wisata Bukit Pentulu Indah. Hasil penelitian ini mendukung penelitian yang dilakukan oleh Sopyan (2015) bahwa terdapat pengaruh yang positif dan signifikan antara Servicescape terhadap Revisit Intention melalui Visitor Satisfaction sebagai variabel intervening.

\section{Penutup dan Saran}

\section{Simpulan}

Berdasarkan hasil analisis data yang terkumpul dari kuisioner mengenai Attraction dan Servicescape terhadap Revisit Intention dengan Visitor Satisfaction sebagai variabel intervening studi pada Obyek Wisata Bukit Pentulu Indah, pada 100 responden maka dapat diambil kesimpulan sebagai berikut:

1. Pengujian hipotesis pertama (H1) diterima, artinya Attraction memiliki pengaruh yang positif dan sighnifikan terhadap Visitor Satisfaction. Hal ini menunjukan bahwa semakin tinggi Attraction maka semakin tinggi pula Visitor Satisfaction Obyek Wisata Bukit Pentulu Indah . Semakin tinggi daya tarik yang dirasakan Wisatawan maka akan semakin tinggi pula tingkat Visitor Satisfaction.

2. Pengujian Hipotesis ke dua (H2) diterima, artinya Servicescape memiliki pengaruh positif dan sighnifikan terhadap Visitor Satisfaction. Hal inimenunjukan bahwa semakin baik Servicescape maka akan meningkatkan Visitor Satisfaction Obyek Wisata Bukit Pentulu Indah.

3. Pengujian hipotesis ke tiga (H3) diterima, artinya Attraction memiliki pengaruh positif dan sighnifikan terhadap Revisit Intention Hal ini menunjukan bahwa semakin baik Attraction atau daya tari Wisata maka semakin tinggi pula Revisit Intention Obyek Wisata Bukit Pentulu Indah.

4. Pengujian hipotes ke empat (H4) ditolak, artinya Servicescape tidak memiliki pengaruh terhadap Revisit Intention. Hal ini menunjukan bahwa Servicescape tidak dapat dijadikan acuan untuk meningkatkan Revisit Intention Wisatawan Bukit Pentulu Indah.

5. Pengujian Hipotesis ke lima (H5) diterima, artinya visitor Satisfaction memiliki pengaruh positif dan sighnifikan terhadap Revisit Intention. Hal ini menunjukan bahwa semakin tinggi Visitor Satisfaction maka akan dapat meningkatkan Revisit Intention Wisatawan Bukit 
Pentulu Indah., sehingga visitor Satisfaction dapat dijadikan acuan untuk meningkatkan Revisit Intention.

6. Pengujan hipotesis (H6) diterima, artinya Visitor Satisfaction dapat memediasi Attraction terhadap Revisit Intention Obyek Wisata Bukit Pentulu Indah . Hal ini menunjukkan bahwa Attraction yang baik dapat mempengaruhi Visitor Satisfaction yang nantinya akan berpengaruh pada Revisit Intention.

7. Pengujan hipotesis (H7) diterima, artinya Visitor Satisfaction dapat memediasi Servicescape terhadap Revisit Intention Obyek Wisata Bukit Pentulu Indah. Hal ini menunjukkan bahwa Servicescape yang baik dapat mempengaruhi Visitor Satisfaction yang nantinya akan berpengaruh pada Revisit Intention.

\section{Keterbatasan}

Dalam penelitian ini, masih terdapat kekurangan dan keterbatasan. Adanya keterbatasan dalam penelitian yang telah dilakukan, diharapkan dapat memberikan evaluasi dan perbaikan untuk penelitian yang akan datang. Keterbatasan dalam penelitian ini antara lain, yaitu:

1. Berhubung pada penelitian ini hanya sebagian variabel yaitu Attraction, Servicescape serta Visitor Satisfaction yang dapat memepengaruhi Revisit Intention, maka disarankan untuk penelitian selanjutnya untuk meneliti variabel-variabel yang lainnya.

2. Subjek dari penelitian ini adalah semua wisatawan yang pernah melakukan kunjungan ulang wisata di obyek wisata Alam Bukit Pentulu Indah, keterbatasan penelitian dengan menggunakan kuesioner yaitu terkadang jawaban yang diberikan oleh sampel tidak menunjukkan keadaan sesungguhnya.

3. Referensi penelitian terdahulu dalam penelitian ini masih terdapat variabel lain yang lebih tepat, maka sebaiknya penelitian selanjutnya dapat menemukan referensi penelitian terdahulu yang memang sesuai dengan penelitian yang akan dilakukan.

\section{Referensi}

Deasy, V. (2012). Analisis Pengaruh Servicescape terhadap Revisit Intention pada Theme Restaurant dan Non-ThemeStudi Kasus: Nanny"s Pavillion dan Solaria. Skripsi. Universitas indonesia.

Fitriani, R., \& Wilardjo, S. B. (2018). Sadar wisata, kemenarikan fasilitas, jarak, pengaruhnya terhadap minat berkunjung kembali pada objek Wisata Masjid Agung Jawa Tengah di Kota Semarang. JWM (Jurnal Wawasan Manajemen), 5(3), 259-272.

Gegel, P. I. (2006). Industri Pariwisata Indonesia Dalam Globalisasi. Bandung: PT. Refika Aditama.

Ghozali, I. (2011). Aplikasi Analisis multivariate dengan program SPSS19. Semarang: Universitas Diponegoro.

Ghozali, I. (2013). Aplikasi Analisis Multivariate dengan Program IBM SPSS. Semarang: Badan Penerbit Universitas Diponegoro.

Kuncoro, M. (2009). Metode Riset Untuk Bisnis E Ekonomi. Jakarta: Erlangga.

Marpaung, B. (2019). Pengaruh Daya Tarik, Kualitas Pelayanan, Fasilitas dan Keselamatan dengan Kepuasan Wisatawan sebagai Variabel Interventing Terhadap Minat Kunjungan Ulang Wisatawan. Mpu Procuratio, 1(2), 144-155. 
Modjanggo, F., Sudhartono, A., \& Sustri, S. (2015). Faktor-Faktor yang Mempengaruhi Jumlah Pengunjung Ke Objek Ekowisata Pantai Siuri, Desa Toinasa Kecamatan Pamona Barat Kabupaten Poso. Jurnal Warta Rimba, 3(2).

Nurlestari, A. F. (2016). Pengaruh Daya Tarik Wisata Terhadap Niat Kunjungan Ulang Wisatawan Dengan Kepuasan Wisatawan Sebagai Variabel Intervening Pada Taman Safari Indonesia Cisarua Bogor. Jurna Pariwisata, 3.

Sarwono, J. (2009). Analisis Jalur untuk Riset Bisnis dengan SPSS. Yogyakarta: PT Andi.

Setiawina, N. D., \& Yuliarmi, N. N. (2018). Analisis faktor-faktor yang mempengaruhi niat kunjungan kembali wisatawan pada daya tarik wisata di Kabupaten Badung. E-Jurnal Ekonomi dan Bisnis Universitas Udayana, 7, 279-308.

Sopyan, S., \& Widiyanto, I. (2015). Analisi Pengaruh Daya Tarik Wisata dan Kualitas Pelayanan Terhadap Minat Berkunjung Ulang Pengunjung dengan Kepuasan Pengunjung Sebagai Variabel Intervening (Studi pada Cagar Budaya Gedung Lawang Sewu) (Doctoral dissertation, Fakultas Ekonomika dan Bisnis).

Sugiyono. (2009). Memahami Penelitian Kualitatif. Bandung: Alfabeta.

Sugiyono. (2010). Metode Penelitian Kuanti, Kualitatif dan R \& D. Bandung: Alfabeta.

Suheri, D. (2015). Pengaruh Kualitas Pelayanan Departemen Front Officeterhadap Kepuasan Tamu Di Banyan Tree Resort Bintan. Skripsi: Universitas Pendidikan Indonesia.

Tjiptono, F. (2005). Strategi Pemasaran. Yogyakarta: Andi Ofset.

Wardhani, U. E. (2008). Usaha Jasa Pariwisata Jilid I. Klaten : PT Macanan Jaya Cemerlang.

Wibowo, S. F., Sazali, A., \& RP, A. K. (2016). The Influence of Destination Image and Tourist Satisfaction toward Revisit Intention of Setu Babakan Betawi Cultural Village. JRMSIJurnal Riset Manajemen Sains Indonesia, 7(1), 136-156.

Yoeti, O. A. (1985). Pengantar Ilmu Pariwisata. Bandung: Angkasa. 